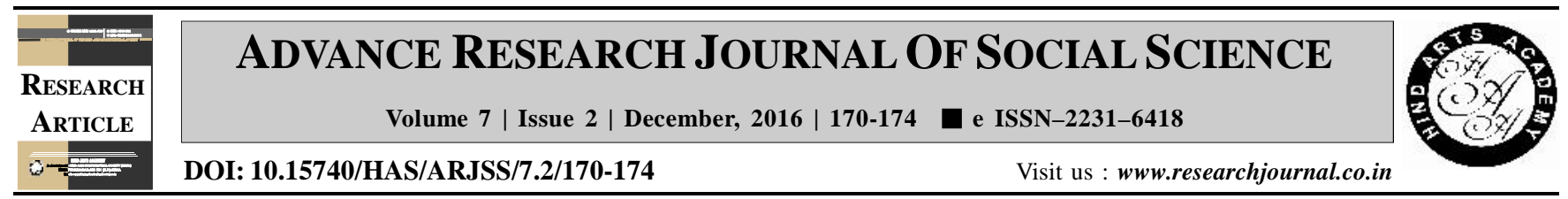

\title{
Study on child perceived barriers to school inclusion in Telangana
}

V. KavithaKiran* and L. Umadevi

Department of Human Development and Family Studies, College of Home Science, HYDERABAD (TELANGANA) INDIA (Email: kiran2adi@yahoo.co.in; umadevi.lingareddy@gmail.com)

\section{ARTICLE INFO :}

$\begin{array}{lll}\text { Received } & : & 28.08 .2016 \\ \text { Revised } & : & 01.10 .2016 \\ \text { Accepted } & : & 15.10 .2016\end{array}$

KEY WORDS :

Barriers, Child perceptions, School facilities, Poverty

\section{HOW TO CITE THIS ARTICLE :}

KavithaKiran, V. and Umadevi, L. (2016).

Study on child perceived barriers to school inclusion in Telangana. Adv. Res. J. Soc. Sci., 7 (2) : 170-174, DOI: 10.15740/

HAS/ARJSS/7.2/170-174.

*Author for correspondence

\begin{abstract}
The present study was taken up in 2 districts of Telangana state to know the barriers to school inclusion. Interview schedule, Focused group discussion, Questionnaire was used to collect the data from 160 out of school children. The study revealed that lack of infrastructure facilities, teacher absenteeism as major school related barriers. Child labour, migration due to poverty as major family related barriers as perceived by the out of school children.
\end{abstract}

